\title{
PENERAPAN PENDEKATAN OPEN-ENDED DALAM MENINGKATKAN KEMAMPUAN KOMUNIKASI SISWA SMP
}

\author{
Gida Kadarisma
}

Prodi Pendidikan Matematika, IKIP Siliwangi

\section{Info Artikel \\ Sejarah Artikel: \\ Diterima 10 Sept 2018 \\ Direvisi 30 Okt 2018 \\ Disetujui 29 Okt 2018 \\ Keywords: Open-Ended Approach, Mathematical Communication}

\section{Paper type:}

Research paper

\section{Abstract}

Mathematical communication skills are very important to be owned by students, but in reality based on research students' mathematical communication skills are still relatively low, therefore it is necessary to have a learning approach that can improve student communication namely Open-ended approach. This study aims to analyze whether the improvement of students' communication skills with open-ended learning is better than those using conventional approaches. The method in this study was quasiexperimental with non-equivalent control group design, the sample in this study were 2 classes in one of the Bandung junior high schools, the instrument in this study were 4 communication questions, the data was processed using SPSS 21, the data processing began with calculate the normalized gain then do the normality test, homogeneity test and mean difference test. Based on the data analysis it was concluded that the improvement of the communication skills of junior high school students whose learning was open-ended was better than those using conventional approaches. Thus open-ended approaches can improve students' communication skills.

\begin{abstract}
Abstrak
Kemampuan komunikasi matematik sangat penting dimiliki oleh siswa, namun pada kenyataannya berdasarkan penelitian kemampuan komunikasi matematik siswa masih tergolong rendah, Oleh karena itu perlu pendekatan pembelajaran yang dapat meningkatkan komunikasi siswa yaitu pendekatan Open-ended. Penelitian ini bertujuan untuk menganalisis apakah peningkatan kemampuan komunikasi siswa yang pembelajaranya menggunakan open-ended lebih baik daripada yang menggunakan pendekatan konvensional. Metode dalam penelitian ini adalah kuasi eksperimen dengan desain kelompok kontrol non-ekuivalen. Sampel dalam penelitian ini adalah 2 kelas di salah satu sekolah SMP kota Bandung. Instrumen dalam penelitian ini sebanyak 4 soal uraian komunikasi, data diolah menggunakan SPSS 21, pengolahan data gain dimulai dari menghitung gain ternormalisasi kemudian dilakukan uji normalitas, uji homogenitas dan uji perbedaan rerata. Berdasarkan analisis data disimpulkan bahwa peningkatan kemampuan komunikasi siswa SMP yang pembelajarannya menggunakan open-ended lebih baik daripada yang menggunakan pendekatan konvensional. Dengan demikian pendekatan open-ended dapat meningkatkan kemampuan komunikasi siswa.
\end{abstract}

\footnotetext{
Alamat korespondensi:

Program Studi Pendidikan Matematika, Universitas Muria Kudus

Kampus UMK Gondangmanis, Bae Kudus Gd. L. lantai 1 Ruang 2 PO. BOX 53 Kudus

Tlp (0291) 438229 Fax. (0291) 437198

E-mail: gidakadarisma@yahoo.com
} 


\section{PENDAHULUAN}

Komunikasi merupakan kemampuan yang sangat penting dimiliki siswa dalam mempelajari matematika, baik siswa sekolah dasar maupun menengah dituntut untuk memiliki kemampuan komunikasi yang baik,Dengan komunikasi matematis Siswa dapat mengorganisisasi proses berpikir matematik secara lisan ataupun tulisan (Ikhsan\&Rizal, 2014) pentingnya komunikasi seperti diungkapkan oleh (Choridah, 2013) bahwa Kemampuan komunikasi matematik juga sangat penting karena matematika pada dasarya adalah bahasa yang syarat dengan notasi dan istilah hingga konsep yang terbentuk dan dipahami serta dimanipulasi oleh siswa, pentingya komunikasi matematik tertuang dalam salah satu tujuan pembelajaran matematika (Depdiknas, 2006) yaitu mengkomunikasikan gagasan dengan simbol, tabel, diagram, atau media lain untuk memperjelas keadaan atau masalah.

Indikator dari komunikasi itu sendiri antara lain (Sumarno, 2004) :1) Menghubungkan benda nyata, gambar, dan diagram ke dalam ide matematika; 2) Menjelaskan ide, situasi dan relasi matematik, secara lisan atau tulisan dengan benda nyata, gambar, grafik dan aljabar;3) menyatakan peristiwa sehari-hari dalam bahasa atau symbol matematik; 4) Mendengarkan, berdiskusi, dan menulis tentang matematika; 5) Membaca dengan pemahaman suatu presentasi matematika tertulis.

Ternyata keadaan dilapangan menunjukkan bahwa kemampuan komunikasi siswa tergolong rendah, termasuk di Kota Cimahi hal ini berdasarkan penelitian dari (Senjayawati, 2015) yang dilihat dari hasil ujian nasional matematika tahun ajaran 2012/2013, hal senada diungkapkan berdasarkan hasil penelitian dari (Rohaeti, 2003) bahwa kemampuan komunikasi matematik siswa rendah baik secara lisan maupun tulisan

Rendahnya kemampuan komunikasi lebih banyak dikarenakan guru kurang menggunakan model pembelajaran yang menuntut siswa aktif berkomunikasi, kebanyakan guru menggunakan model konvensional dalam pembelajarannya hal ini selajan dengan (Darkasyi, Johar, Ahmad, 2014) yang menyatakan bahwa rendahnya kemampuan komunikasi matematik dikarenakan guru lebih aktif menggunakan pendekatan konvensional dalam menyampaikan materi pada peserta didik, hasil serupa didapat dari penelitian (Putra, 2016) yang menyatakan rendahnya kemampuan komunikasi matematik di sebuah MTS diduga karena model pembelajaran yang digunakan guru dikelas. Guna meningkatkan kemampuan komunikasi matematika siswa diperlukan suatu model pembelajaran yang memfasilitasi siswa untuk aktif menyampaikan ide-ide/gagasangagasan matematika (Noviarny, Murtono, Ulya: 2018)

Oleh karena itu dibutuhkan pendekatan pembelajaran yang dapat meningkatkan kemampuan komunikasi siswa, yaitu pendekatan Open-Ended. Pendekatan open ended yaitu pendekatan pembelajaran yang menuntut pola pikir yang terbuka, proses berpikir siswa tidak hanya fokus pada satu proses atau hasil. Pada pendekatan Open-Ended tujuan pemberian masalah bukan untuk menemukan jawaban akan tetapi menemukan strategi, cara, dan pendekatan yang berbeda untuk sampai pada jawaban dari masalah yang diberikan (Melianingsih \&Sugiman 2015), Dalam pendekatan open ended, siswa diberikan berbagai macam masalah dari suatu topik, kemudian diselesaikan dengan caranya sendiri melalui berbagai cara. masalah yang dapat diambil bisa dalam masalah matematika yang kontekstual (Shimada\& Becker,1997). Masalah kontekstual yang terbuka dapat melatih siswa untuk berdiskusi dan mengemukakan pendapatnya, Dengan begitu melalui pembelajaran dengan pendekatan OpenEnded diharapkan kemampuan komunikasi siswa dapat meningkat, sehingga tujuan dari penelitian ini adalah untuk mengetahui apakah peningkatan kemampuan komunikasi matematik siswa yang pembelajarannya menggunakan open-ended lebih baik daripada yang menggunakan pendekatan konvensional

\section{METODE PENELITIAN}

Metode dalam penelitian ini adalah kuasi eksperimen, sampel tidak dipilih secara acak tetapi peneliti menerima keadaan subjek seadanya (Ruseffendi, 2005), dengan design kelompok kontrol non ekuivalen. Sampel dalam penelitian ini adalah 2 kelas di Salah satu sekolah SMP kota Cimahi, kelas eksperimen merupakan kelas yang mendapat pembelajaran dengan pendekatan Open-Ended sedangkan kelas kontrol merupakan kelas dengan pendekatan konvensional, siswa pada kelas eksperimen sebanyak 28 siswa sedangkan pada kelas kontrol sebanyak 31 siswa, sebelum dan sesudah perlakuan diberikan tes uraian komunikasi matematik sebanyak 4 soal. Kemampuan Komunikasi matematik dalam penelitian ini yaitu : 1) Menghubungkan benda nyata, gambar, dan diagram ke dalam ide matematika; 2) Menjelaskan ide, situasi dan relasi matematik, secara tulisan dengan benda nyata, gambar, 
grafik dan aljabar; 3) menyatakan peristiwa sehari-hari dalam bahasa atau symbol matematik. Terdapat 6 kali pertemuan dalam topik lingkaran. Berikut adalah desain penelitiannya :

$$
\begin{gathered}
0 \times 0 \\
-\cdots \\
0
\end{gathered}
$$

O : Soal Pretes $=$ soal postes

- - - - : Sampel dipilih tidak acak

$\mathrm{X} \quad$ : Kelas dengan pendekatan open ended

\section{HASIL DAN PEMBAHASAN}

Dalam bagian ini akan dijelaskan pengolahan data gain ternormalisasi kelas yang menggunakan pembelajaran open ended dan pembelajaran konvensional setelah 6 pertemuan. Menghitung gain ternormalisasi digunakan rumus

$$
\begin{aligned}
& \text { N-Gain }=\frac{\text { S.Postes }- \text { S.Pretes }}{\text { S.MSI-SPretes }} \\
& \text { Hake (Meltzer, 2002) }
\end{aligned}
$$

Sebelum menguji rerata mana yang lebih baik, maka dilakukan uji normalitas terlebih dahulu. Uji normalitas dilakukan dengan bantuan software SPSS 21, dengan kriteria Sig. $\geq 0.05$ maka data berdistribusi normal, sebaliknya jika Sig. $<0.05$ data tidak berdistribusi normal. Berikut hasil pengolahan datanya :

Tabel 1. Uji Normalitas Shapiro-Wilk Kelas Eksperimen dan Kontrol

\begin{tabular}{llll}
\hline Kelas & Statistic & Df & Sig. \\
\hline Eksperimen & 0.919 & 28 & 0.63 \\
\hline Kontrol & 0.938 & 31 & 0.75 \\
\hline
\end{tabular}

Berdasarkan tabel 1 diperoleh bahwa Nilai Sig. untuk kelas eksperimen dan kontrol masing-masing adalah 0.063 dan 0.07 , nilai tersebut $\geq 0.05$ berdasarkan kriteria maka baik kelas ekperimen dan kelas kontrol berdistribusi normal. Setelah diketahui data berdistribusi normal maka dilanjutkan dengan uji homogenitas varians antara kelas yang menggunakan open ended dengan yang menggunakan pendekatan konvensional. Uji Homogenitas menggunakan Levene test dengan bantuan software SPSS, dengan Hipotesis :

$\mathrm{H}_{\mathrm{o}}: \sigma_{1}=\sigma_{2}$ (Varians kedua kelas homogen) $\mathrm{H}_{\mathrm{a}}$ $\sigma_{1} \neq$

$\sigma_{2}$ (Varians kedua kelas tidak homogen) dengan kriteria jika nilai Sig. $\geq 0.05$ maka $\mathrm{H}_{\mathrm{o}}$ diterima, dan sebaliknya jika Sig. $<\mathrm{H}_{\mathrm{o}}$ ditolak, berikut ini hasil uji homogenitas kedua kelas :
Tabel 2. Uji Homogenitas Varians

\begin{tabular}{cc}
\hline \multicolumn{2}{c}{$\begin{array}{c}\text { Levene's Test for Equality } \\
\text { of Variances }\end{array}$} \\
\hline F & Sig. \\
\hline 0.468 & 0.496 \\
\hline
\end{tabular}

Dari Tabel 2 diperoleh nilai Sig. sebesar 0.496 ,nilai ini $\geq 0.05$ maka $H_{o}$ diterima dengan kata lain dapat disimpulkan bahwa varians kedua kelas homogen. Berikutnya akan diuji hipotesis menggunakan uji signifikansi perbedaan dua rata-rata dengan uji-t, menggunakan bantuan software SPSS, dengan hipotesis :

$\mathrm{H}_{\mathrm{o}}: \mu_{1}=\mu_{2} \quad$ (Tidak terdapat perbedaan Peningkatan Kemampuan Komunikasi Siswa yang menggunakan Open-Ended dengan yang menggunakan pendekatan konvensional

$\mathrm{H}_{\mathrm{a}}: \mu_{1}>\mu_{2} \quad$ (Peningkatan Kemampuan Komunikasi Siswa yang pembelajarannya menggunakan Open-Ended lebih baik dari yang menggunakan pendekatan konvensional)

dengan kriteria jika nilai Sig. $\geq 0.05$ maka $\mathrm{H}_{\mathrm{o}}$ diterima, dan sebaliknya jika Sig. $<\mathrm{H}_{\mathrm{o}}$ ditolak, berikut ini hasil uji perbedaan dua rerata kedua kelas :

Tabel 3. Uji Signifikansi Perbedaan dua Rerata

\begin{tabular}{lccc}
\hline \multicolumn{1}{c}{ Kelas } & T & Df & $\begin{array}{c}\text { Sig.2 } \\
\text { tailed }\end{array}$ \\
\hline $\begin{array}{l}\text { Equal } \\
\text { Variances }\end{array}$ & 2.475 & 57 & 0.016 \\
Assumed & & & \\
\hline
\end{tabular}

Dari tabel 3. Dapat kita lihat bahwa Nilai Sig. 2 Tailed sebesar 0.016 maka nilai Sig1 tailed $=\frac{\text { Sig.2 Tailed }}{2}=0.008$, nilai ini $<0.05$ maka $\mathrm{H}_{\mathrm{o}}$ ditolak dapat disimpulkan bahwa Peningkatan Kemampuan Komunikasi Siswa yang pembelajarannya menggunakan OpenEnded lebih baik dari yang menggunakan pendekatan konvensional.

Pada awal pembelajaran, siswa di kelas eksperimen mengalami kebingungan karena mereka pertama kali mendapat pembelajaran dengan soal-soal terbuka, namun setelah sering menggunakan pembelajaran dengan Open-Ended mereka lebih terbiasa dan lebih antusias dalam melaksanakan KBM dibandingkan dengan kelas yang menggunakan pendekatan konvensional. Dengan pendekatan Open-Ended siswa dituntut untuk aktif dan kreatif dalam mengkomunikasikan materi serta lebih pandai dalam menjelaskan ide dan situasi matematik. Soal-soal tebuka pada pendekatan open-enden 
membuat siswa lebih aktif berdiskusi dan menulis tentang matematik. Keberhasilan OpenEnded pada penelitian ini sejalan dengan penelitian dari (Sulianto, 2011) yang memaparkan bahwa pendekan Open-Ended lebih efektif dalam pembelajaran segitiga. Penelitian lain yang sejalan, dari (Hidayat\&Sariningsih, 2018) menemukan bahwa Kemampuan pemecahan masalah matematika siswa SMP pada materi keliling dan luas persegi panjang dengan pembelajaran open ended mencapai ketuntasan belajar. Dengan demikian, pendekatan OpenEnded dapat meningkatkan kemampuan komunikasi siswa SMP

\section{SIMPULAN}

Berdasarkan hasil dan pembahasan dapat disimpulkan bahwa peningkatan kemampuan komunikasi matematik yang pembelajarannya menggunakan Open-Ended lebih baik daripada yang menggunkan pendekatan konvensional.

\section{UCAPAN TERIMAKASIH}

Penulis ucapkan terimakasih kepada semua pihak yang telah membantu dalam kelancaran penelitian ini. Penulis juga mengucapkan terimakasih kepada segenap tim Pengelola Jurnal Anargya yang telah memberikan kesempatan kepada penulis untuk mempublikasikan karya ilmiahnya

\section{DAFTAR PUSTAKA}

Choridah, D. T. 2013. Peran Pembelajaran Berbasis Masalah untuk Meningkatkan Kemampuan Komunikasi dan Berpikir Kreatif serta Disposisi Matematis Siswa SMA. Infinity Journal, 2(2), 194-202.

Darkasyi, M., Johar, R., \& Ahmad, A. 2014. Peningkatan kemampuan komunikasi matematis dan motivasi siswa dengan pembelajaran pendekatan quantum learning pada siswa SMP Negeri 5 Lhokseumawe. Jurnal Didaktik Matematika, 1(1).

Depdiknas. 2006. Panduan Penyusunan Kurikulum Tingkat Satuan Pendidikan. Badan Standar Nasional Pendidikan: Jakarta.

Hidayat, W., \& Sariningsih, R. 2018. Kemampuan Pemecahan Masalah Matematis dan Adversity Quotient Siswa SMP Melalui Pembelajaran Open Ended. JNPM (Jurnal Nasional Pendidikan Matematika), 2(1), 109-118.

Ikhsan, M., \& Rizal, S. 2014. Meningkatkan kemampuan pemahaman dan komunikasi matematis siswa sekolah menengah atas melalui model pembelajaran generatif. Jurnal Didaktik Matematika, 1(2).

Melianingsih, N., \& Sugiman, S. 2015. Keefektifan pendekatan Open-Ended dan problem solving pada pembelajaran bangun ruang sisi datar di SMP. Jurnal Riset Pendidikan Matematika, 2(2), 211223.

Meltzer, D.E. 2002. The Relationsip Between Mathematics Preparation and Conceptual Learning gains in Physics: Posisible "Hidden Variable" in Diagnostic Pretest Scores. American Journal of Physics. 70(7).

Noviarny, D. A., Murtono, M., \& Ulya, H. 2018. Model Think Talk Write Berbantuan Media Monomat Meningkatkan Kemampuan Komunikasi Matematika Siswa Sekolah Dasar. Anargya: Jurnal Ilmiah Pendidikan Matematika, 1(1).

Rohaeti, EE. 2003. Pembelajaran Matematika dengan Menggunakan Metode Improve untuk Meningkatkan Pemahaman dan Kemampuan Komunikasi Matematik siswa SLTP. Tesis PPS UPI. Bandung : tidak dipublikasikan

Ruseffendi, E.T. 2005. Dasar-Dasar Penelitian Pendidikan \& Bidang Non-Eksakta Lainnya. Bandung: Tarsito.

Senjayawati, E. 2015. Penerapan Pendekatan Kontekstual untuk Meningkatkan Kemampuan Komunikasi Matematik Siswa SMk di Kota Cimahi. Didaktik, 9(1), 33-39.

Shimada, S. dan Becker, J.P. 1997. (Editor) The Open-Ended Approach. A New Proposal for Teaching Mathematics. Virginia: National Council of Teachers of Mathematics

Sumarmo, U. 2004. Pembelajaran Matematika untuk Mendukung Pelaksanaan Kurikulum Berbasis Kompetensi. Makalah disajikan pada Pelatihan Guru Matematika di Jurusan Matematika ITB. April 2004.

Sulianto, J. 2011. Keefektifan Model Pembelajaran Kontekstual dengan pendekatan open ended dalam aspek penalaran dan pemecahan masalah pada materi segitiga di kelas VII. Malih Peddas (Majalah Ilmiah Pendidikan Dasar), 1(1).

Putra, F. G. 2016. Pengaruh Model Pembelajaran Reflektif dengan Pendekatan Matematika Realistik Bernuansa 
Gida Kadarisma

Anargya: Jurnal Pendidikan Matematika, Vol. 1 No.2, Oktober 2018

Keislaman terhadap Kemampuan

Komunikasi Matematis. Al-Jabar:

Jurnal Pendidikan Matematika,7(2),

203-210. 
